within Soviet territorial waters round the southern end of Kamchatka, across the Okhotsk Sea and round the northern end of Sakhalin).

The first three of these routes involve passing through fairly narrow straitsthe Tsushima Strait is much the largest in total width, but has the two islands of Tsushima and Iki in the middle, breaking it up into three channels. The Tsugaru Strait, with a width of twelve miles, is the most convenient for ships approaching the Japan Sea from the east.

The route to the north of the Kurils and Sakhalin is much longer than the other three and is more difficult for traffic in winter owing to the conditions of navigation in the Okhotsk Sea and Tatarsky Strait (between Sakhalin and the Siberian mainland). Even at Vladivostok the harbour has to be kept open with ice-breakers in winter, but shipping has only to cope with ice on approaching the coast. The Okhotsk Sea, on the other hand, is infested with floating ice for half the year, especially in the area north of Sakhalin. Tatarsky Strait is entirely frozen and is crossed by sledge traffic from the mainland to Sakhalin for three months in each year.

BRIA N R OBERTS

\title{
PROTOCOL OF THE EAST GREENLAND TREATY OF 9 JULY 1924
}

On 24 August 1945 the Danish Rigsdag ratified a Protocol signed in Copenhagen on 18 July 1945 between Denmark and Norway relating to an alteration in the conditions governing the termination of the East Greenland Treaty of 9 July 1924 between Denmark and Norway. A translation of the text of the Protocol is given below:

"The Royal Danish Government and the Royal Norwegian Government have agreed as follows:

According to the terms of Article 9 of the East Greenland Treaty of 9th July, 1924 between Denmark and Norway, which reads as follows:

'This Treaty shall come into force on July 10th 1924 and shall be irrevocable for twenty years with an extension for a similar period, provided it is not denounced by either of the parties not less than two years before the expiry of the twenty years period',

the period during which it could be denounced expired on July 10th 1942 .

In 1942, it was agreed between the two Governments that the provisions of Article 9 of the Treaty could not operate so long as Denmark and Norway were militarily occupied, and that therefore both parties should retain the right to denounce the Treaty with due observance to two years notice, provided that notice was given within a reasonable period after both countries had regained their freedom.

It has now been agreed that the term of notice defined in Article 9 shall expire on July 10th 1946, and the Treaty remain in force provided it is not terminated by one of the parties giving two years notice before the last mentioned date to terminate it on July 10 th 1948 . 
In confirmation whereof the Ministers of Foreign Affairs of both countries have, subject to ratification, signed this protocol, which has been prepared in two copies in the Danish and Norwegian languages, in Copenhagen on July 18th 1945."

(Signed) J. Christmas Möller Trygve Iie.

The Treaty of 9 July 1924 provided that: "In East Greenland, by which is understood that part of the east coast of Greenland with its adjacent waters which lies from Lindenov Fjord to Nordostrundingen, with the exception of the district of Angmagssalik", there should be free access for the ships of both parties, for hunting and fishing by the subjects of both parties, and for the occupation of land by those subjects for their own use. The Treaty also laid down that differences between the two parties should be submitted to the Hague Court, and in notes which were exchanged simultaneously with the signature of the Treaty, each party reserved its point of view regarding questions of principle. The rights accorded to Norwegians under this Treaty were subsequently extended to British subjects by an exchange of notes on 4 June 1925 and to French citizens by the exchange of notes on 19 October 1925, in view of the most-favoured-nation clauses of Treaties of Commerce between Denmark and Great Britain and Denmark and France respectively.

\section{DEVELOPMENT AND WELFARE IN EAST GREENLAND}

[Review of "The East Greenlanders: Possibilities of Existence, their Production and Consumption", by Ejnar Mikkelsen, in collaboration with P. P. Sveistrup. Meddelelser om Gronland, Bd. 134, No. 2, 1944, pp. 1-244.]

In this report the responsible Danish official, the Inspector for East Greenland, a traveller of wide experience, summarises in great detail the background and the story of the Danish colonising work. in East Greenland. This work was started in 1894 through the initiative of Gustav Holm. "Half a century has elapsed since the Eskimo population of East Greenland... were made to take the immense and dangerous leap from [the] stone age...." Mikkelsen provides the full picture, from "Living Conditions in East Greenland in Pre-Historic Times" to "Health Conditions of the East Greenlanders after the Colonisation"; from migration routes of the past to the state of the teeth of those alive to-day; the hunting, the trading and the travelling; the consumption of imported foods, the vital statistics; the stocks of seals; the isolation and the contacts; the objects of the whole enterprise and speculations about the future.

Apart from being a compendium of information, the chief interest and importance of this report resides in its description of the development and welfare of a backward race reduced to its very simplest. It is a small, controlled experiment in colonisation, using that term in the British Imperial sense of to-day.

What was and is the Danish objective? Following Gustav Holm's wintering at Angmagssalik in 1884-85, it was realised "that the remainder of the East 